\title{
Grapes adaptive resistance to summer stresses in the conditions of climate change
}

\author{
Nataliya Nenko*, Galina Kiseleva, Irina Ilina, Viktoriya Sokolova, and Natalia \\ Zaporozhets \\ Federal State Budget Scientific Institution «North Caucasian Federal Scientific Center of \\ Horticulture, Viticulture, Wine-making», str. 40 Let Pobedy, 39, 350901 Krasnodar, Russia
}

\begin{abstract}
The purpose of this work is to study the grapes adaptive resistance to the summer stress factors by physiologo-biochemical parameters, to identify varieties adapted for cultivation in the AnapaTaman region. The objects of research were following varieties: Krasnostop, Dostoynyi - euro-american origin; Vostorg - amur-american; Zarif - eastern-european; Aligote - western-european, Kristall- euro-amuramerican. The grapes adaptive stability was achieved by maintaining a stable ratio of photosynthetic pigments in the leaves during the summer growing season, increasing the content of carotenoids, proline and abscisic acid. The lowest values of the chlorophyll/carotenoid ratio (2.47-2.69) were found in the Zarif variety, the maximum increase in the proline content (8.9 times larger) was observed in the Kristall variety. It is shown that the protective response induction is more expressed in the varieties Dostoynyi, Krasnostop, Crystal, and Vostorg and they proved to be more adaptive in comparison with the Aligote and Zarif varieties in the summer of 2020 .
\end{abstract}

\section{Introduction}

The problems of cultivated grape varieties resistance to high temperatures and low water availability have become particularly relevant in connection with climate change in the Anapa-Taman zone of the Krasnodar region. During the last ten years an increase in the average annual air temperature by $1.7^{\circ} \mathrm{C}$, the maximum temperature by $2.8^{\circ} \mathrm{C}$ and a decrease in the summer total precipitation by $40 \mathrm{~mm}$ were recorded [1]. Therefore, varieties with resistance to summer high temperatures and drought are of great interest for the grape production and breeding. Physiological and biochemical parameters as diagnostic criteria for identifying highly adaptive grape varieties, as well as other cultivated crops, are widely used throughout the world [2-4].

Drought-resistant grape varieties are characterized by a high water-holding capacity of the leaves, a higher water potential due to the retention of water by osmotically active agents, as well as the use of other mechanisms. The transpiration of leaf tissues is normalized in grape plants in arid conditions, cell homeostasis and the photosynthetic

\footnotetext{
* Corresponding author: nenko.nataliya@yandex.ru
} 
processes activity are preserved due to the accumulation of osmolytes (sucrose, proline) [57].

The water potential has a great influence on stomatal conductance. In the absence of a compensating mechanism, for example, the inability to osmotic rearrangement, there is a loss of turgor, which leads to the stomata closure [8] because of abscisic acid and thus reduces the water loss during transpiration. In addition to osmotic regulation, abscisic acid also affects the regulation of aquaporin activity and auxin antagonism [9-12].

Summer elevated temperatures, combined with insufficient water supply, lead to overheating of leaf tissues, inhibition of photosynthesis and mineral nutrition of the vine. A decrease in the photosynthesis intensity leads to a decrease in the assimilates outflow from the leaves to the berries and shoots [13].

The stress factors of the summer period cause the development of oxidative stress in the leaf mesophyll cells, which leads to the activation of lipid peroxidation. Reactive oxygen species purification by antioxidants (carotenoids, ascorbic acid, various forms of peroxidases) is one of the strategies of drought adaptation. It has been shown that peroxidase is most active in the vine during the berry ripening period, possibly due to its participation in the chlorophyll degradation [14].

It is a common fact that the precipitation deficit is a limiting factor for the grapes growth. The water content in grape berries, the accumulation of sugar and anthocyanins in them under the influence of elevated temperatures and drought is of great importance, since the yield value is the final indicator of the plant's ability to adapt to arid habitat conditions $[15,16]$.

In recent years, great progress has been made in the study of the grape genome, in the detection of genes whose expression increased under drought conditions, and in the loci localization that regulate the network of the genes that are activated under water and hightemperature stress. In Vitis vinifera, the VviNCED1 and VviNCED2 genes are associated with ABA synthesis and activated during water deficit [17].

The purpose of this work is to study the grapes adaptive resistance to the summer stress factors by physiological and biochemical indicators, to identify varieties adapted for cultivation in the Anapa-Taman zone.

\section{Materials and methods}

The objects of research were following varieties: Krasnostop, Dostoynyi - euro-american origin; Vostorg - amur-american; Zarif - eastern-european; Aligote - western-european, Kristall (control) - euro-amur-american.

The content of leaf pigments was determined on a Unico 2800 spectrophotometer (USA); the content of proline and abscisic acid was determined on a capillary electrophoresis system Capel [18]; the peroxidase activity was determined by the Boyarkin method [19]. The obtained data were processed by the methods of variation statistics [20].

\section{Results and discussion}

In the summer of 2020 , the average monthly air temperature in June was $+22.3^{\circ} \mathrm{C}$, the maximum air temperature $-+33^{\circ} \mathrm{C}$, the minimum air temperature $-+13{ }^{\circ} \mathrm{C}$. July was the warmest and driest, with an average monthly air temperature of $+26^{\circ} \mathrm{C}$, a maximum air temperature of $+35^{\circ} \mathrm{C}$, and a minimum air temperature of $+19^{\circ} \mathrm{C}$. In August, the average monthly air temperature was $+25^{\circ} \mathrm{C}$, the maximum $-+36{ }^{\circ} \mathrm{C}$, the minimum $-+16{ }^{\circ} \mathrm{C}$. The total precipitation in June was $7.7 \mathrm{~mm}$; in July $-2.3 \mathrm{~mm}$, in August $-2.7 \mathrm{~mm}$. 
The total water content of the studied grape varieties decreased by the end of summer and was 66.05-74.97\% in August, depending on the variety. The exception was the Vostorg variety, the leaves water content of which decreased only in the warmest and driest month - July, in August it was recovered and amounted to $74.97 \%$. According to the leaves water content, the Vostorg variety stood out as the most stable. Varieties Aligote and Zarif were the most unstable by this indicator, reducing the leaves water content to $9.5 \%$ and $7.8 \%$, respectively (Table).

Table 1. Grape leaves water content during the summer in $2020, \%$

\begin{tabular}{|l|c|c|c|}
\hline \multirow{2}{*}{ Variety } & \multicolumn{3}{|c|}{ Leaves water content, \% } \\
\cline { 2 - 4 } & June & July & August \\
\hline Dostoynyi & $75,16 \pm 2,31$ & $71,50 \pm 1,23$ & $69,85 \pm 0,90$ \\
\hline Krasnostop & $77,87 \pm 1,53$ & $71,07 \pm 2,35$ & $70,53 \pm 0,61$ \\
\hline Kristall & $76,82 \pm 2,81$ & $71,41 \pm 1,81$ & $70,92 \pm 1,07$ \\
\hline Vostorg & $74,64 \pm 1,61$ & $72,29 \pm 0,86$ & $74,97 \pm 1,72$ \\
\hline Aligote & $75,58 \pm 2,40$ & $70,21 \pm 1,25$ & $66,05 \pm 1,21$ \\
\hline Zarif & $76,96 \pm 2,64$ & $72,17 \pm 1,26$ & $69,08 \pm 2,50$ \\
\hline LSD 0,5 & 1,42 & 1,53 & 1,82 \\
\hline
\end{tabular}

During a drought the photosynthesis depression in plants and pigment complex reorganization are took place. In our studies, the content of leaves total chlorophylls in the studied varieties decreased in July in comparison with June, due to the impact of hightemperature and water stresses, except for the Dostoynyi variety. In August, with a decrease in stress exposure, the content of total chlorophylls increased in the varieties Krasnostop, Kristall, Vostorg and decreased in the varieties Dostoynyi, Aligote and Zarif. The most stable indicator of the chlorophylls amount during the summer was observed in the Kristall variety (8.64-9.64 mg/g dry matter), which is indicative of its stability (Fig. 1).

Excessive solar insolation can damage grape leaves. The main strategy that plants use to protect themselves from this kind of photodamage is to dissipate additional light in the heat form. The excess energy is transferred from the chlorophyll to other pigments, carotenoids, which can then release it as heat. An increase in the proportion of carotenoids in the pigment complex, that means a decrease in the chlorophyll/carotenoid ratio, indicates their participation in the photoprotective function [2].

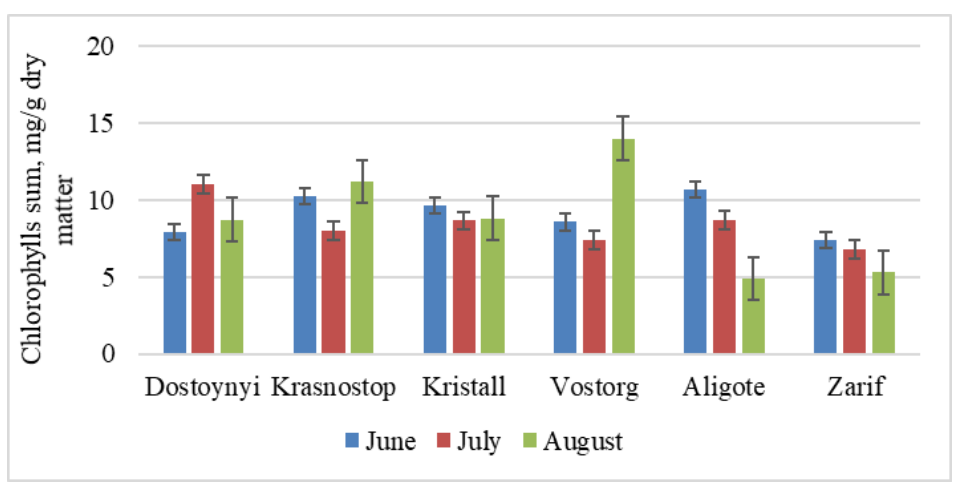

Fig. 1. The chlorophylls sum content $(\mathrm{a}+\mathrm{b})$ in grape leaves in the summer of 2020 LSD0.5: June 0.42 ; July -0.27 ; August -0.45 .

In our studies, the lowest values of the chlorophyll/carotenoid ratio (2.47-2.69) were found in the Zarif variety (Fig. 2). 


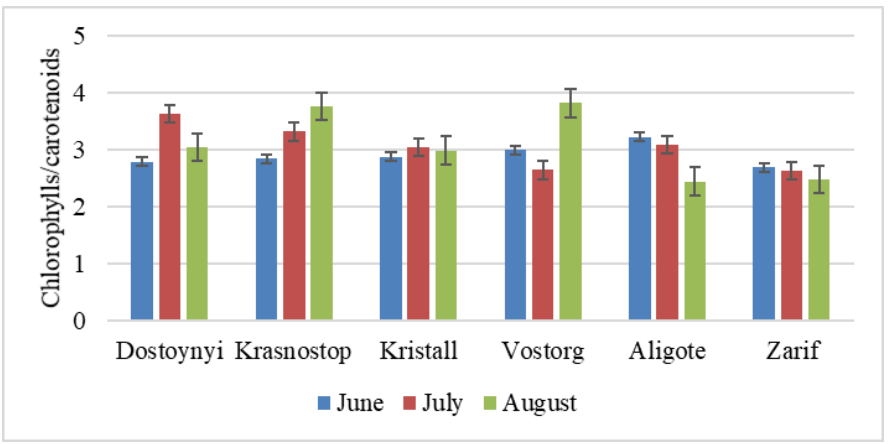

Fig. 2. The chlorophylls/carotenoids ratio in grape leaves in the summer of 2020 LSD0.5: June 0.42 ; July -0.27 ; August -0.45 .

In the Kristall grape variety, the ratio of pigment forms remained relatively stable during the summer, while fluctuations in this parameter in other studied varieties were observed. Despite the numerous data obtained on other plants, a relationship between changes in the content, the ratio of photosynthetic pigments forms and drought in grape plants wasn't found.

The grape plants resistance to high temperatures and drought is achieved by an increase in the content of the osmoprotector proline, which provides a high water-holding capacity of the cytoplasm. In August, compared to July, the Kristall variety showed an 8.9-fold increase in the proline content, while in the varieties Dostoynyi and Krasnostop, its content increased by 4.4 and 6.8 times, respectively, which proves the active role of this amino acid in the response to summer stressful conditions., The role of proline in the formation of protective mechanisms is small in the other studied grape varieties (Fig. 3).

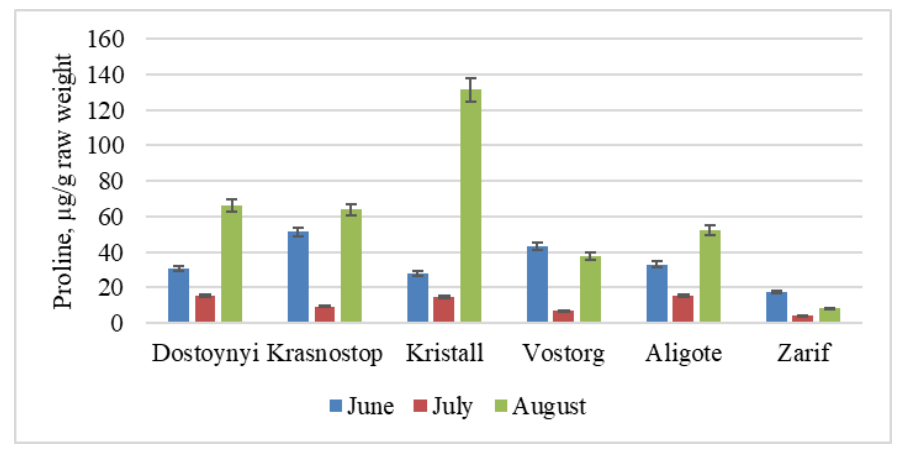

Fig 3. Quantitative parameters of proline in grape leaves in the summer of 2020 LSD 0.5: June 0.42 ; July -0.27 ; August -0.45 .

The accumulation of proline in grape leaves is regulated by the level of abscisic acid (ABA), which activates its synthesis and content. An increase in the ABA content under conditions of water stress contributes to the stomata closure, preventing the process of transpiration. Thus, the quantitative indicators of abscisic acid in the Kristall variety in August increased by 4.08 times compared to July. In the varieties Dostoynyi and Krasnostop, its content also increased by 4.2 and 4.0 times, respectively. The contribution of ABA to the protective response to the stresses of the summer period is small in the other studied varieties (Fig. 4).

The plants adaptation to high temperatures and drought involves an increase in the activity of antioxidant enzymes, in particular, peroxidase. An increase in the activity of peroxidase indicates a stress reaction and inhibition of growth processes, i.e. it acts as a reliable marker of 
stress [22]. In early summer, increased peroxidase activity was observed in the Dostoynyi variety - 3.5-31.1 times higher than in other varieties (Fig. 5).

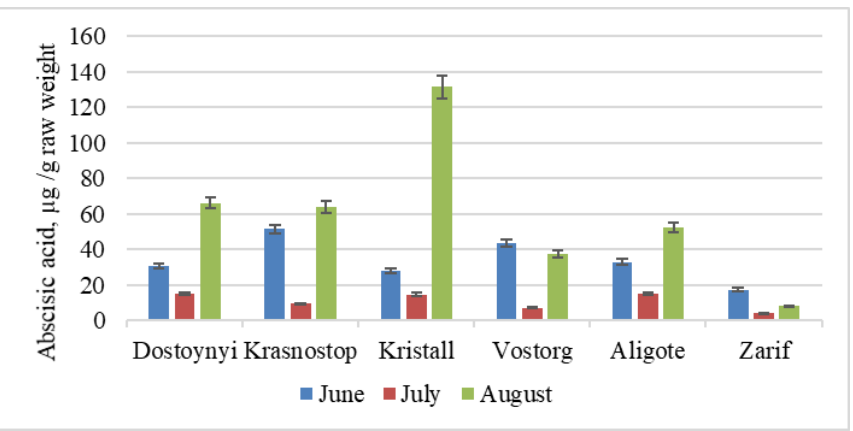

Fig. 4. The abscisic acid content in grape leaves in the summer of 2020

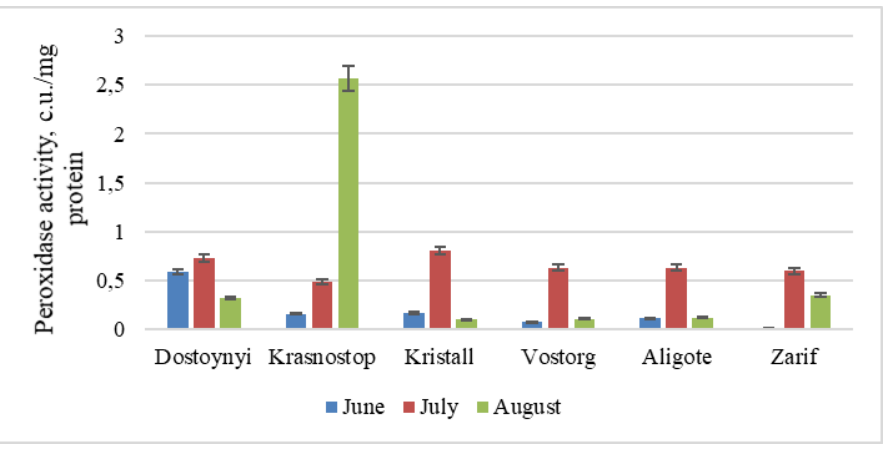

Fig. 5. Peroxidase activity in grape leaves in the summer of 2020

During the extreme period for grape plants (July) the activity of peroxidase in all the studied varieties increased in varying degrees.

The greatest contribution to the suppression of oxidative stress at this time was made by peroxidase in the Zarif variety (an increase in activity by 31.5 times), in the rest of the studied varieties, the peroxidase activity increased by $1.23-8.18$ times. In the post-stress period (August) the activity of this enzyme decreased in comparison with July due to the performance of its functions, with the exception of the Krasnostop variety, where an increase was observed in 5.24 times. It is possible that the increase in peroxidase activity in the Krasnostop variety is associated with the beginning of berry maturation, which coincides with the leaf aging beginning. A similar fact was noted by romanian researchers in the table grape varieties leaves [14].

\section{Conclusion}

Differences in hydration, the content of photosynthetic pigments, proline, abscisic acid, and peroxidase activity in the grapes leaf tissues of were revealed during the summer of 2020.

The grapes adaptive stability was achieved by maintaining a stable ratio of photosynthetic pigments in the leaves during the summer growing season, increasing the proportion of carotenoids in the pigment complex, and increasing the level of proline and abscisic acid. It is shown that the lowest values of the chlorophyll/carotenoid ratio (2.472.69) were found in the Zarif variety, indicating a large role of carotenoids in the performance of the protection function. The maximum increase in the proline content (8.9 times) was observed in the Kristall variety. The greatest contribution of peroxidase to the 
suppression of oxidative stress in a hostile period was found in the Zarif variety (an increase in activity by 31.5 times).

It is established that the adaptation of the studied grape varieties to summer hostile conditions causes a sequental changes in the metabolic processes associated with an increase in the content of compounds with a protective-regulating effect, the accumulation of which is variety-specific.

It is shown that the induction of the protective response is more pronounced in the varieties Dostoynyi, Krasnostop, Kristall, and Vostorg. These varieties proved to be more adaptive in comparison with the Aligote and Zarif varieties in the conditions of the summer period of 2020 .

\section{Acknowledgments}

The reported study was funded by RFBR and Krasnodar Territory Administration according to the research project № 19-44-230021 r_a.

\section{References}

1. M.D. Larkina, D.V. Dergachev, V.S. Petrov, M.I. Pankin, A.A. Marmorshtein, Fruit growing and viticulture of South Russia, 63(3), 60 (2020)

2. N.I. Nenko, I.A. Ilina, V.S. Petrov, M.A. Sundyreva, V.V. Sokolova, N.M. Zaporozhets, G.K. Kiseleva, T.V. Skhalyaho, Bulletin of the Russian agricultural science, 5, 40 (2019)

3. A.V. Ryndin, O.G. Belous, V.I. Malyarovskaya, Z.V. Pritula, Yu.S. Abilfazova, A.M. Kozhevnikova, Agricultural biology, 3, 40 (2014)

4. N. Bhusal, S.G. Han, T.M. Yoon, Scientia Horticulturae, 246, 535 (2019)

5. M.R. Conesa, J.M. De La Rosa, R. Domingo, S. Banon, Scientia Horticulturae, 202(20), 9 (2016)

6. L.C. Carvalho, J.L. Coito, S. Colaço, M. Sangiogo, S. Amâncio, Plant, Cell and Environment, 38, 777 (2015)

7. I. Serra, A. Strever, P.A. Myburgh, A. Deloire, Aust. J. Grape Wine Res., 20(1), 1 (2014)

8. K. Fort, J. Fraga, D. Grossi, M.A. Walker, Journal of the American Society for Horticultural Science, 142, 36 (2017)

9. J. Lozano-Juste, A.F. Alrefaei, P.L. Rodriguez, Trends in Plant Science, 25(12), 1179 (2020)

10. W. Xu, W. Shen, J. Ma, R. Ya, Q. Zheng, N. Wu, Environmental and Experimental Botany, 172, 103999 (2020)

11. S. Dayer, S.D. Tyerman, T. Garnett, V. Pagay, Acta Horticulturae, 1188, 227 (2017)

12. A. Pou, H. Medrano, J. Flexas, S.D. Tyerman, Plant Cell Environ., 36, 828 (2013)

13. B.P. Holzapfel, J.P. Smith, S.K. Field, W.J. Hardie, Horticultural reviews, 37 (2010)

14. R.V. Filimon, L. Rotaru, R.M. Filimon, South African Journal of Enology and Viticulture, 37(1), 1 (2016)

15. J.C. Gouot, J.P. Smith, B.P. Holzapfel, A.R. Walker, C. Barril, Journal of Experimental Botany, 70(2), 397 (2019)

16. D.H. Greer, C. Weston, Functional Plant Biology, 37(3), 206 (2010) 
17. L. Rossdeutsch, E. Edwards, S.J. Cookson, F. Barrieu, G.A. Gambetta, S. Delrot, N. Ollat, BMC Plant Biol., 16, 91 (2016)

18. N.I. Nenko, G.K. Kiseleva, Modern methodologies, tools for assessment and selection of breeding material for horticultural crops and grapes, 61 (2017)

19. A.I. Ermakov, V.V. Arasimovich, N.P. Yarosh, Biochemical research methods of plants, 430 (1987)

20. B.A. Dospekhov Field experiment methodology, 463 (1979)

21. Y.Y. Luo, R.X. Li, Q.S. Jiang, R. Bai, Nordic Journal of Botany, 23(14), 1 (2019)

22. Yu.E. Kolupaev, Yu.V. Karpec, L.F. Kabashnikova. Applied Biochemistry and Microbiology, 55(5), 419 (2019) 